\title{
Drug Induced Lupus Erythematosus Due to Capecitabine and Bevacizumab Treatment Presenting with Prolonged Thrombocytopenia
}

\author{
ERSIN OZASLAN ${ }^{1}$, ERAY EROGLU ${ }^{2}$, KEVSER GOK $^{3}$, SONER SENEL ${ }^{3}$, SULEYMAN \\ BALDANE $^{4}$, LUTFI AKYOL ${ }^{5}$, METIN OZKAN $^{1}$ \\ ${ }^{1}$ Department of Medical Oncology, Erciyes University, Faculty of Medicine, Kayseri, Turkey \\ ${ }^{2}$ Department of Internal Medicine, Erciyes University, Faculty of Medicine, Kayseri, Turkey \\ ${ }^{3}$ Department of Rheumatology, Erciyes University, Faculty of Medicine, Kayseri, Turkey \\ ${ }^{4}$ Department of Internal Medicine, Selcuk University, Faculty of Medicine, Konya, Turkey \\ ${ }^{5}$ Department of Rheumatology, Ondokuz Mayis University, Faculty of Medicine, Samsun, Turkey
}

\begin{abstract}
Drug induced lupus erythematosus (DILE) is a syndrome that is formed by lupus-like symptoms and laboratory characteristics. Capecitabine is an orally administered tumor-selective fluoropyrimidine that acts as a prodrug of 5-Fluorouracil and bevacizumab is an antivascular endothelial growth factor (anti-VEGF) antibody, both are used for the treatment of patients with colorectal cancer. Herein we report the first case of DILE in a 68-year-old woman who presented with arthralgia, myalgia and prolonged thrombocytopenia after receiving capecitabine and bevacizumab combination treatment as palliative treatment for metastatic colon cancer. Platelet levels were increased and joint complaints disappeared in the first week of hydroxychloroquine and methylprednisolone treatment after chemotherapy had been discontinued. In conclusion, physicians should be alert to the possibility of DILE in patients presenting with thrombocytopenia under a capecitabine and bevacizumab chemotherapy regimen.
\end{abstract}

Keywords: capecitabine, drug induced lupus erythematosus, thrombocytopenia.

\section{INTRODUCTION}

Systemic lupus erythematosus (SLE) is an autoimmune disease characterized by the presence of autoantibodies against nuclear and cytoplasmic antigens [1]. Drug induced lupus erythematosus (DILE) is a syndrome that consists of lupus-like symptoms and laboratory characteristics. More than 80 drugs have been associated with DILE (hydralazine, procainamide, diuretics, calcium channel blockers, angiotensin converting enzyme inhibitors, beta-blockers, anti-tumor necrosis factor agents, etc.) [2].

Capecitabine is an orally administered tumorselective fluoropyrimidine that acts as a prodrug of 5-Fluorouracil. Capecitabine is currently used for the treatment of patients with breast cancer, colorectal cancer and gastric cancer. The most common side effects of capecitabine are mucositis, hand-foot syndrome, skin reactions and some gastrointestinal side effects including nausea, vomiting and diarrhea [3].

Bevacizumab is an antivascular endothelial growth factor (anti-VEGF) antibody that is used for the treatment of patients with colorectal cancer, ovarian cancer, and glioblastoma multiforme. The most common toxicities associated with bevacizumab are dry mouth, mucositis, cough, anorexia, nausea, vomiting, diarrhea, headache, arterial thromboembolism, hemorrhage, hypertension, proteinuria, and gastrointestinal perforation. While bevacizumab is rarely associated with bone marrow toxicity, capecitabine may be associated with mild bone marrow suppression [4].

To the best of our knowledge there is no case of DILE which is associated with bevacizumab and capecitabine in the current literature. Herein, we report the first case of DILE that is associated with bevacizumab and capecitabine in a metastatic colorectal cancer patient who presented with thrombocytopenia and arthralgia.

\section{CASE REPORT}

A 68-year-old woman was admitted to our hospital with abdominal pain in October 2013. Multiple liver masses were observed on abdominal ultrasonography and colonoscopy revealed a tumorlike mass in the sigmoid colon. The biopsy specimen of the mass was reported as adenocarcinoma. She was initially treated with low anterior resection, 
liver metastasectomy and retroperitoneal lymph node resection and sigmoid colon adenocarcinoma assessed as American Joint Committee on Cancer stage IV (pT4 pN1 M1). Palliative chemotherapy was started with capecitabine $2000 \mathrm{mg} / \mathrm{m}^{2}$ (1-14 days), oxaliplatin $130 \mathrm{mg} / \mathrm{m}^{2}$ (1 day) and bevacizumab $7.5 \mathrm{mg} / \mathrm{kg}$ (1 day), as part of a 21-day cycle. Her medical history only included hypertension and she had used losartan for the last five years. After the second chemotherapy cycle partial response was observed in metastatic masses in the liver and complete blood count levels were normal. Positron-emission tomography-scan (PET-scan) showed complete metabolic response after the administration of the fourth chemotherapy cycle. Then maintenance therapy was planned with capecitabine $1650 \mathrm{mg} / \mathrm{m}^{2}$ for 1-14 days of a 21-day cycle and bevacizumab $5 \mathrm{mg} / \mathrm{kg}$, for 1 day of a 28-day cycle. Maintenance therapy was not started due to platelet levels which were decreased at the beginning of the therapy (Platelet levels: $52 \times$ $10^{3} / \mu 1$, normal range (NR): 130-400). Fifteen days later platelet levels were over the level of $100 \times$ $10^{3} / \mu \mathrm{l}$ and maintenance therapy was started.

After the second cycle platelet levels were decreased to a level of $80 \times 10^{3} / \mu 1$; they subsequently decreased to $74 \times 10^{3} / \mu 1$ and $53 \times 10^{3} / \mu 1$ during the third cycle in a 30 day period. White blood cell and hemoglobin levels were normal. Chemotherapy was stopped and the patient was referred to the hematology department for thrombocytopenia. The results of viral serologic tests were normal and peripheral blood smear showed no atypical cells except for thrombocytopenia. She complained of arthralgia and myalgia over a period of two weeks when she was admitted to the hematology department. There were no skin rashes in her history and examination. The autoimmune profile workup revealed positive anti nuclear antibody (ANA) results with a titer of 1:10000 with homogeneous pattern and positive anti doublestranded DNA antibody (anti-ds DNA) results (>800, NR: 0-100), ANA profile revealed antihistone and anti-nucleosome antibodies were positive. Anti-SSA (Ro-52), anti-SSA (Ro-60) and anti-SSB (anti-La) antibodies were all negative. She was referred to the rheumatology department with these findings. Her platelet levels were $84 \times 10^{3} / \mu 1$ when first admitted to the rheumatology department. Rheumatoid factor and anti-cyclic-citrullinated peptide test results were within normal range. Serum complement levels were normal and both direct and indirect coombs tests were all negative. Urine test results were normal. Anti-cardiolipin IgG was over 120 (NR: 0-12) and anti-cardiolipin IgM was over 120 (NR: 0-12). Anti Beta-2 glycoprotein levels (anti $\beta$-2GP) were as follows: anti $\beta$-2GP IgA was 57 (NR: 0-20), anti $\beta-2$ GP IgG was 30 (NR: $0-20$ ) and anti $\beta-2$ GP IgM was over 200 (NR: 0-20). Lupus anticoagulant test results were positive as screening was 83.6 second (NR: $31-44$ ), confirmation was 40.5 second (NR: $30-38$ ), and the ratio was three positive with the range of 2.06 (NR: 0.8-1.2). The erythrocyte sedimentation rate was $49 \mathrm{~mm} / \mathrm{h}$ (NR: 3-20) and C-reactive protein level was $26.8 \mathrm{mg} / \mathrm{L}$ (NR: 0-6). The brucella agglutination test was negative. She was diagnosed with DILE. Therefore, chemotherapy was ceased by the oncology department and she began treatment with oral metilprednisolon $48 \mathrm{mg}$ per 24 hours, hydroxychloroquine $200 \mathrm{mg}$ per 12 hours, and aspirin $100 \mathrm{mg}$ per 24 hours. Seven days later her platelet levels were increased to $137 \times 10^{3} / \mu 1$.

\section{DISCUSSION}

There are many publications in the literature about drug induced lupus syndromes. However, diagnostic and classification criteria for DILE have not been well established. The following guidelines [2] are commonly used: I) Treatment with suspected drug of at least 1 month duration or usually longer, II) Symptoms/organ involvement: arthralgia, myalgia, fever, serositis and dermatological rash, III) Laboratory findings: ANA, anti-histone in the absence of other antibody specificities (i.e anti-Sm, anti-dsDNA, ENA: extractable nuclear antigen), IV) Improvement of symptoms within days/weeks of drug discontinuation. Three forms of DILE have been identified: a) The systemic form of DILE that involves different organs. Almost $90 \%$ of the patients present with arthralgia, 50\% have myalgia, fever and malaise among other symptoms. It presents with positive anti-histone test. b) The subacute cutaneous form of drug induced lupus erythematosus (SCLE) is more common in females and generally presents with photodistributed skin rashes and positive anti-Ro test, while positive results for anti-dsDNA and anti-La tests were not decisive. c) The chronic cutaneous form is rare and usually related to fluorouracil compounds $[3,4]$.

Only five cases [5-9] of capecitabine-induced SCLE have been reported in the literature so far. 
Two of these cases $[5,6]$ had breast cancer, two of them $[7,8]$ had gastric cancers and one of them [9] had colorectal cancer. Additionally, one of the patients with breast cancer was diagnosed with both capecitabine induced SCLE and palmoplantar erythrodysesthesia [10].

Merlin et al. [11] reported a case of capecitabine associated discoid lupus erythematosus. In this case lupus autoantibodies were all negative. Vihinen et al. [12] diagnosed SCLE in a patient with breast cancer under paclitaxel and bevacizumab therapy. They suggested that SCLE was most probably induced by paclitaxel with great possibility and they concluded that the role of bevacizumab is thought to be unlikely. To the best of our knowledge, ours is the first case of DILE associated with capecitabine and bevacizumab in the literature. We also suggest that capecitabine could be the responsible drug for DILE in our case because the numbers of cases with drug induced lupus syndromes are more frequent with capecitabine than with bevacizumab and the side effects of bevacizumab on bone marrow are very rare.
There are some case reports of drug induced lupus syndromes with some members of the fluoropyrimidine group including 5-FU and 5-FU agents (e.g, tegafur and uracil-tegafur) [13-16]. They were associated with chronic cutaneous lupus syndromes and flares of systemic lupus erythematosus.

Capecitabine is the prodrug of 5-fluorouracil and it has rarely been associated with SCLE cases. However, Almagro et al. [17] reported a case of 5-FU induced SCLE. Otherwise, there has been no reported case showing the association between 5-FU and DILE in the literature.

In conclusion, in our case, we cannot certainly say that the reason of prolonged thrombocytopenia depends on hematologic toxicity of capecitabine or DILE. However, physcians should be alert to the possibility of DILE in patients with gastrointestinal cancer under bevacizumab and capecitabine treatment if they are observed to have arthralgia and myalgia with thrombocytopenia. In addition, if skin rashes are detected differential diagnosis should include SCLE.

Lupusul eritematos indus medicamentos (DILE) este un sindrom caracterizat prin simptome lupus-like şi modificări paraclinice caracteristice. Capecitabinul este un anti-tumoral selectiv din clasa fluoropirimidinelor administrat oral şi acționează ca un prodrog al 5-Fluorouracilului. Bevacizumabul este un anticorp monoclonal îndreptat împotriva factorului de creştere vascular endotelial (VEGF). Ambele medicamente sunt utile în tratamentul cancerului colorectal. Prezentăm un caz clinic al unei paciente în vârstă de 68 de ani care după administrarea capecitabinului şi a bevacizumabului drept tratament paleativ pentru cancer metastatic colorectal a dezvoltat artralgii, mialgii şi trombocitopenie prelungită. Artralgiile au dispărut şi numărul trombocitelor a crescut după oprirea medicației şi administrarea timp de o săptămână a hidroxiclorochinului şi a metilprednisolonului. În concluzie, medicii ar trebui să fie atenți la posibilitatea dezvoltării DILE la pacienții ce se prezintă cu trombocitopenie atunci când le este administrată terapia cu capecitabină şi bevacizumab.

Correspondence to: Süleyman Baldane M.D., Department of Internal Medicine,

Selcuk University, Faculty of Medicine, Konya, Turkey

Postal Code: 42075, Phone: +90 332 2244385, Fax: +90 3524378659

E-mail: baldane42@hotmail.com

\section{REFERENCES}

1. REEFMAN E, KUIPER H, JONKMAN MF, et al. Skin sensitivity to UVB irradiation in systemic lupus erythematosus is not related to the level of apoptosis induction in keratinocytes. Rheumatology. 2006; 45:538-44.

2. SARZİ-PUTTINI P, ATZENI F, CAPSONİ F, et al. Drug induced lupus erythematosus. Autoimmunity. 2005; 38:507-18.

3. MARZANO AV, VEZZOLİ P, CROSTİ C. Drug-induced lupus: an update on its dermatologic aspects. Lupus. $2009 ;$ 18:935-40.

4. KATZ U, ZANDMAN-GODDARD G. Drug-induced lupus: an update. Autoimmun Rev. 2010; 10:46-50.

5. KINDEM S, LLOMBART B, REQUENA C, et al. Subacute cutaneous lupus erythematosus after treatment with capecitabine. J Dermatol. 2013; 40:75-6. 
6. FERNANDES NF, ROSENBACH M, ELENITSAS R, KIST JM. Subacute cutaneous lupus erythematosus associated with capecitabine monotherapy. Arch Dermatol. 2009; 145:340-1.

7. KO JH, HSIEH CI, CHOU CY, WANG KH. Capecitabine-induced subacute cutaneous lupus erythematosus: report of a case with positive rechallenge test. J Dermatol. 2013; 40:939-40.

8. WEGER W, KRÄNKE B, GERGER A, et al. Occurrence of subacute cutaneous lupus erythematosusafter treatment with fluorouracil and capecitabine. J Am Acad Dermatol. 2008; 59:4-6.

9. FLORİSTAN U, FELTES RA, SENDAGORTA E, et al. Subacute cutaneous lupus erythematosus induced by capecitabine. Clin Exp Dermatol. 2009; 34:328-9.

10. WIESENTHAL A, MATHERNE R, GIBBSON B. Capecitabine-induced systemic lupuserythematosus and palmoplantar erythrodysesthesia. J Drugs Dermatol. 2012; 11:769-71.

11. MERLIN F, PROCHILO T, KILDANI B, et al. Discoid lupus erythematosus (DLE)-like lesions induced by capecitabine. Int J Colorectal Dis. 2008; 23:715-6.

12. VIIHINEN P, PAİJA O, KIVISAARİ A, et al. Cutaneous lupus erythematosus after treatment with paclitaxel and bevacizumab for metastatic breast cancer: a case report. J Med Case Rep. 2011; 5:243.

13. DUDLEY K, MICETICH K, MASSA MC. Erythema with features of seborrheic dermatitis and lupus erythematosus associated with systemic 5-fluorouracil. Cutis. 1987; 39:64-6.

14. KLUGER N, BESSIS D, GUILLLOT B. Chronic cutaneous lupus flare induced by systemic 5-fluorouracil. J Dermatolog Treat. 2006; 17:51-3.

15. MOAZZAM N, MALIK AA, MEHDİ SA, POTTİ A. Treatment side effects. Case 3. Fluorouracil-induced exacerbation of systemic lupus erythematosus. J Clin Oncol. 2002; 20:3032-4.

16. YOSHIMASU T, HIROİ A, UEDE K, FURUKAWA F. Discoid lupus erythematosus (DLE)-like lesion induced by uraciltegafur (UFT). Eur J Dermatol. 2001; 11:54-7.

17. ALMAGRO BM, STEYLS MC, NAVARRO NL, et al. Occurrence of subacute cutaneous lupus erythematosus after treatment with systemic fluorouracil. J Clin Oncol. 2011; 29:613-5.

Received May 1, 2015 